\title{
Women and Gender in the Bible and the Biblical World
}

\section{Cat Quine* \\ Bereaved Mothers and Masculine Queens: The Political Use of Maternal Grief in 1-2 Kings}

https://doi.org/10.1515/opth-2020-0120

received April 27, 2020; accepted June 1, 2020

\begin{abstract}
Recent research demonstrates that maternal grief functions paradigmatically to epitomize despair and sorrow in the Hebrew Bible. These literary uses of maternal grief reinforce the stereotype of womanhood, defined by devotion to children and anguish at their loss. In 1-2 Kings, narratives about unnamed bereaved mothers are used politically to create a contrast with named biblical queens who lose their sons but never grieve for them. Although 1-2 Kings names the queen mothers alongside the male rulers, these mothers have no agency or when they do, they act more like men than women. Neo-Assyrian inscriptions attest the masculinity of royal female power, and this article argues that conceptions of royal female power in Judah were similar. By contrasting the masculine queens with stereotyped "real men" and "real women," traditional gender performances literarily overcome the institution of queenship. While the queens are polemicized, unnamed mothers emerge as the female heroes of Kings. Royal female power is demoted beneath reproductive ability and emotional responses to children, while the gender fluidity of royal power is circumscribed.
\end{abstract}

Keywords: maternal grief, masculinity, queens, gender, politics

Despite its masculine title, 1-2 Kings displays a surprising amount of interest in bereaved mothers. Five narratives about unnamed bereaved mothers seeking help, restitution, or justice for their dead child are found therein (1 Kgs 3:16-28; 14:1-18; 17:17-24; 2 Kgs 4:8-37; 6:24-32). To these we can add 2 Kgs 4:1-7, which has a mother's concern for the life of her children as its central theme. ${ }^{1}$ These narratives all involve women in the tenth-ninth centuries BCE and, with the exception of Jeroboam's wife (1 Kgs 14:1-18), none of the women are royal. Similarly, yet contrastingly, the only four royal women to receive extended mention in Kings also lived in the tenth-ninth centuries BCE and three are bereaved of their sons. ${ }^{2}$ Yet, the texts - and modern commentators - do not dwell on their losses. The royal women receive no sympathy when their husbands and sons die, and the royal bereaved mothers are all portrayed negatively. The nonroyal women, on the other hand, are portrayed either positively and able to save their children (1 Kgs 17:9; 2 Kgs 4:1-7; 4:8-37) or less negatively than one might expect given their questionable actions (1 Kgs 3:16-28; 2 Kgs 6:24-32). Finally, after Athaliah's death (2 Kgs 11), women vanish from the narratives and only Huldah the prophetess appears in the late seventh century (2 Kgs 22). Politics are evidently at play in the dialectic surrounding queens and mothers.

1 Two of these women are also widows (1 Kgs 17:9; 2 Kgs 4:1), which affords them rhetorical power as their presence denotes hardship and their treatment is a standard by which other characters can be judged; Galpaz-Feller, "The Widow."

2 Maacah, Jezebel, and Athaliah.

\footnotetext{
* Corresponding author: Cat Quine, Merton College, University of Oxford, Oxford, United Kingdom of Great Britain and Northern Ireland, e-mail: cat.quine@nottingham.ac.uk
} 
Kozlova has recently demonstrated that maternal grief was an archetype of mourning in ancient Israel, known to be so powerful that it could be applied paradigmatically to a variety of situations in the Hebrew Bible. ${ }^{3}$ Although biblical mourning has attracted significant attention in recent years, few studies pause to consider the absence of expected grief and mourning. ${ }^{4}$ One would expect that the queen mother was symbolically the mother par excellence in the kingdom - the woman whose son reached the highest of heights. ${ }^{5}$ Indeed, the name of these mothers has been preserved throughout millennia in 1-2 Kings, yet they do not conform to readers' expectations of mothers. They rarely have agency as characters and when they do, they have no maternal role. The queens do not respond emotionally when their children die - in contrast to the unnamed women who do-and they thus appear distant, uncaring, unfemale, and unnatural. Their responses are those expected of men, not mothers. ${ }^{6}$ Masculine women are not permitted in the literary world of Kings, however, and so the biblical narratives conspire to replace them with "real men.” Asa, Jehu, and Jehoiada, respectively, demonstrate what good men should do - limit female power and uphold gender boundaries. The extent to which this performance of masculinity is intertwined with faith in Yhwh makes for uncomfortable reading for feminist interpreters. While the men realign power with "true" masculinity, the emphasis on motherhood reassigns female power to the sphere of reproduction and childcare. All the passages about bereaved mothers come before Jezebel and Athaliah's reigns and cultivate expectations of how women - that is, mothers - should behave. Needless to say, Jezebel and Athaliah do not match these expectations. Their masculine performances of power at the point of their children's death create discord; the gender role being performed does not match the gender role that ought to be performed at such a crucial moment.

In Section 1, I analyse specific passages about non-royal, (non)bereaved mothers in 1-2 Kings, highlighting how the women's desperation, distance from royalty, and seeking prophetic intervention result in positive portrayals and their children being saved. In Section 2, I discuss bereaved mothers and kings, demonstrating that when kings are involved the mothers are portrayed less positively, and the children die. Section 3 then turns to the portrayals of queens and queen mothers in 1-2 Kings, demonstrating how their lack of mourning and/or response to their child's death conspires against them and underscores their masculinity. Finally, Section 4 notes the masculinity of queens in the Neo-Assyrian royal inscriptions, which was acceptable and praiseworthy, in contrast to 1-2 Kings where the royal women who act like men are portrayed as aberrative. ${ }^{7}$ Ultimately, I argue that 1-2 Kings does not just critique specific Israelite and Judahite royal women but also critiques a political system that permitted (or admitted) the gender fluidity of royal female roles. Kings "corrects" this reality by elevating motherhood over queenship as the most important female role. In 1-2 Kings, good mothers save their sons while bad queens doom the nations. ${ }^{8}$

\footnotetext{
3 Kozlova, Maternal Grief; see also Lee, "Mothers Bewailing;” Joyce, "Lamentations;” Kalmonofsky, "Women of God.” 4 Some recent studies include, for example, Olyan's Biblical Mourning, which is helpful for understanding the larger concepts but rarely touches on 1-2 Kings and never on passages of interest for this study. Elsewhere, Janzen ("The Root Škl”) studies Psalm 35 and Wiley ("Faith and Loss”) focuses on Abraham and Job. David’s mourning also attracts attention, e.g., Zimran, "Look;” Berger, “On Patterning;” Bosworth, “David;” Zhixiong, David’s Mourning. More generally, see Bosworth, “Understanding Grief."

5 Certain goddesses would have been the divine mother par excellence but in terms of human symbolism, if the kings represented the people, the queen mother represented the mother of the people.

6 Kozlova, Maternal Grief, 8-15 (and literature therein) highlights differences between men and women in parental grief, which may be influenced by societal gender norms. Men tend to be more active than women, learning new skills, making memorials, and distracting themselves from, or silencing, feelings of loss. Women are more likely to exhibit emotional distress responses, particularly with young children, as the psychological boundaries between mother and child overlap significantly in the first year of life. Maacah, Jezebel, and Athaliah do not exhibit any emotional responses to their sons' deaths and Jezebel and Athaliah act powerfully, decisively, and even violently when their sons die - responses that are at odds with authorial expectations of mothers.

7 See especially, Svärd, Women and Power, 83-5; Quick, "My Lord the Queen,” 454-8.

8 Fuchs, "Characterization," 134-5, argues that the institution of motherhood "is a powerful patriarchal mechanism," ensuring that men maintain control of women through control of reproductive powers and patrilineal inheritance patterns.
} 


\section{Non-royal, (non)bereaved mothers in Kings}

1 Kings 17:8-24 and 2 Kings 4:1-7 both feature unnamed women who are widows and mothers and face the loss of their children. ${ }^{9}$ In 1 Kgs 17, Elijah is sent by Yhwh to Zarephath where a widow provides food to him with the last of her stock and it miraculously multiplies. ${ }^{10}$ Her son then falls ill and dies, and Elijah performs a miracle of resuscitation. ${ }^{11}$ This woman's son is threatened twice, first by starvation (17:12) and then by illness (17:17); both times Yhwh saves him. 2 Kings 4:1-7, meanwhile, tells the story of a widow of a member of the company of prophets whose children are about to be taken into slavery as payment for debt. ${ }^{12}$ Elisha performs a miracle of multiplication and the children collect the oil for her to sell to pay her debts. ${ }^{13}$ The passage shows the familial side of prophecy, where the women and children who usually remain hidden in the background of confrontations between prophets and kings now come to the fore. ${ }^{14}$ In both passages, widowhood is central; both women lack men to provide for them and their children, so they turn to the prophets. They do not have the power to change their own situations but their determination and faith result in their children being saved.

To these we can add the story of the great woman of Shunem (2 Kgs 4:8-37), who is a very different character. ${ }^{15}$ Her husband remains alive throughout and she is wealthy, providing for Elisha out of surplus rather than her last crumbs. She does not begin the narrative with a son but gains one halfway through, whether she wanted him or not (4:14-17). ${ }^{16}$ Her unsought son dies abruptly (4:18-20) and the woman makes great haste to travel to Elisha and demand that he resuscitates him, which he does (4:21-37). This tale has many similarities to $1 \mathrm{Kgs}$ 17: both feature a mother who houses a prophet, loses a son, turns to that prophet in desperation, and are rewarded with their sons' lives. Neither woman prays to Yhwh themselves nor approaches the prophets with respect; the widow of Zarephath accuses Elijah of causing the death of her son (1 Kgs 17:18), and the woman of Shunem seizes Elisha's feet (or genitals?) and refuses to leave without him (2 Kgs 4:27-30). ${ }^{17}$ Their desperation is rewarded with life and commentators praise the woman of Shunem, in particular, for her initiative and determination. Thus, for example, Parker states that the woman of Shunem "acts with astonishing authority as she commands, argues, dismisses, and

In my view, 1-2 Kings proves Fuchs' point: the institution of motherhood is utilized to endorse women who were subservient to men, while undermining women whose status permitted them a position above men.

92 Kings 4:1-7 might be a variation of 1 Kgs 17:8-24; Park, Kings, 40.

10 Zarephath is significant as it was close to Jezebel's home city of Sidon. The widow of Zarephath thus offers a parallel to Jezebel and her location permits Yhwh and Elijah to demonstrate their power outside of Israel's borders; Wyatt, "Jezebel, Elijah,” 435-58; Sweeney, Kings, 208-13.

11 Lasine, "Life and Death," 120, notes that the text displays no interest in life after death - all that matters is that life returns. Elijah's ritual has also attracted scholarly attention (e.g., Lasine, "Life and Death," 121-5; Gray, Kings, 382-4), though it is sparse on the exact theological/magical details.

12 Later Jewish tradition gave this anonymous woman an identity, viewing her as the wife of Obadiah, steward of Ahab, on account of his god-fearing; Cogan and Tadmor, Kings, 55.

13 This little story is often skipped over in favour of its grander sequel in 2 Kgs 4:8-37, but Shemesh, "Elisha," demonstrates its importance. Children being sold into slavery as a result of debt is seen elsewhere in Exod 21:7; Isa 50:1; Neh 5:4-5 and also in the Code of Hammurabi (§117); Gray, Kings, 492; Cogan and Tadmor, Kings, 56.

14 Park, Kings, 42-3.

15 This text has attracted a significant amount of scholarly interest, not least because of the complex and possibly negative portrayal of Elisha. See, for example, Shields, "Man of God;” Amit, "A Prophet Tested;” Dijk-Hemmes, "The Great Woman;" Hepner, "Three's a Crowd;" Roncace, "Elisha."

16 Numerous commentators observe that the woman did not ask for a son and shows no interest in wanting one - only Gehazi and Elisha decide that she should have one. Shields, "Man of God," 62, notes that her husband is said to be too old to have children and her response to Elisha informing her that she will conceive is comparable to those found in the rape narratives of 2 Sam 13:12; Judg 19:23. Amit, “A Prophet Tested," 286-8, observes that while Hannah explicitly asked for a son, this woman does not and god is not mentioned in the promise of this child. Hepner, "Three's a Crowd," 387-97 (cf. Dijk-Hemmes, "The Great Woman,” 226-7), argues that Elisha fathered the woman's child, creating a negative comparison with Abimelech.

17 Kalmonofsky highlights bereaved mothers' propensity for religious innovation, seen here in the women's determination to deny death and go outside of mainstream religion to demand that their sons be brought back to life; Kalmonofsky, "Women of God,” cf. Sered, "Mother Love.” 
prevails over male characters." ${ }^{18}$ Long observes that "the Shunammite is clearheaded and purposeful in her urgent concentration." ${ }^{19}$ Cohn notes that she "takes matters into her own hands," "the initiative is all hers," and "her husband" is defined in relation to her. ${ }^{20}$ Readers' responses to the woman of Shunem are interesting, because the traits that result in her praise often become a point of critique when applied to a queen. ${ }^{21}$ It is also notable that the only mention of royalty in these narratives is rejected, when the woman of Shunem turns down Elisha's offer to speak to the king on her behalf ( 2 Kgs 4:13). So why are these stories preserved in 1-2 Kings? The usual answer is that they demonstrate the power of the prophets at the expense of the kings. ${ }^{22}$ In other words, the stories about women were preserved because they were really about men. I suggest, however, that these narratives have additional rhetorical potential when the unnamed women are compared with the infamous queens. For if these stories make statements about the kings without directly mentioning them, it should not be surprising that they also make statements about the queens.

\section{Bereaved mothers and kings}

The first mention of children and kings in 1-2 Kings immediately introduces the theme of maternal grief. In 1 Kgs 3:16-28, two prostitutes come before king Solomon, one of whom claims that the other accidentally killed her son and switched his body with her living son while she slept (3:16-22). ${ }^{23}$ The statement that the women were prostitutes highlights their lack of kinship and legal support and emphasizes the social difference between them and the king. ${ }^{24}$ It also explains why two women were living together with their children but no men. ${ }^{25}$ The lack of evidence puts the king in a difficult position but Solomon "solves" the case by suggesting that the remaining child should be killed, leading one woman to give up her claim to him. Provan states that "the identity of the true mother, the one who gives up her child out of love is thus revealed to Solomon." 26 Notably, however, this woman may not be the biological mother of the child. 1 Kings 3:26 says that she was the "one whose son was alive," but this is only indicated by her response to Solomon's proposal; if it was evident whose son was alive in the first place, there would be no case to answer. Due to the lack of differentiation between the two women, this "true mother" could well be the one who killed the first child but was simply first (or loudest) to protest Solomon's idea. ${ }^{27}$ Regardless, Solomon's view - and thus the reader's - is that this woman deserves to be given the child because of her emotional response to the threat of his death. ${ }^{28} \mathrm{~A}$ few things should be emphasized here: first, the king's response to a dead child and two desperate mothers is to get a sword and endanger another child. ${ }^{29}$

18 Parker, Valuable and Vulnerable, 140.

19 Long, Kings, 57.

20 Cohn, Kings, 27-8.

21 In particular, Jezebel's dominance of Ahab is often viewed negatively.

22 Thus, Long, for example, characterizes 2 Kgs 4:1-7 as a "prophetic legend" -one of several narratives "which bring Elisha into full view, while ostensibly recording events of importance to Jehoram's reign;” Long, Kings, 50.

23 Prostitutes coming before a king was a folklore motif seen in other ancient Near Eastern literature; Gray, Kings, 127-8.

24 Hens-Piazza, Kings, 42.

25 Sweeney, Kings, 82.

26 Provan, Kings, 51.

27 Indeed, this woman had already proven her desperation to have a child, having switched her dead son's body with the living child in the first place.

28 Highlighted by the identification of her "seat of reckoning" as her womb (רחמיה); Gray, Kings, 129.

29 Solomon's solution can be read sympathetically, as using a sword to bring life rather than death (e.g., Provan, Kings, 52). Or it can be read suspiciously; perhaps Solomon's great wisdom was simply to cut the child in half-a fair, if not happy, outcome given the lack of evidence. In this case, his true wisdom would be manifested in him listening to a woman and changing his mind. Either way, the sword is the symbol of the king's justice and a sword threatened but not used is the symbol of royal wisdom. 
Second, true mothers - and perhaps, good women - are indicated by their attachment to their children and their behaviour when they die or are threatened. Through their responses, the women judge themselves in the eyes of the reader. ${ }^{30}$

We now turn to the wife of Jeroboam I (1 Kgs 14:1-18), who bears the distinction of being the only royal woman given a narrative but not a name or speech in 1-2 Kings. ${ }^{31}$ Although often referred to as "wife of Jeroboam," the narrative centres around her motherhood and her attempt to determine the fate of her sick son, Abijah. Jeroboam tells her to disguise herself and travel to the prophet Ahijah (14:1-3). She does so, and Ahijah informs her that her son will die when she enters Tirzah (14:12-13), all descendents will be cut off from the house of Jeroboam (14:10-12), and his kingship will be replaced by another (14:14). The passage is full of irony: the woman disguises herself to go to a blind prophet (14:4), ${ }^{32}$ the king being raised up by Yhwh against Jeroboam (14:14) parallels Jeroboam raising up his hand against Rehoboam וירם יד המלך; 1 Kgs 11:26), ${ }^{33}$ and, in contrast to the Davidic line, the Israelite royal line appears doomed at its inception. ${ }^{34}$ Differently, Branch reads the narrative in light of spousal abuse, noting the negative implications of the woman's passivity, silence, and obedience for her relationship with Jeroboam. ${ }^{35}$

Although the lack of name and speech may imply the subjugation of the wife of Jeroboam, it may also reflect authorial ambivalence. Notably, this woman's status and anonymity permit comparison with two other mothers in 1-2 Kings. First, the only other northern queen mentioned is the infamous Jezebel who is violently opposed to Yhwh's prophets, loses both her sons in ignominious circumstances, and her husband's house is ended violently. Second, the woman of Shunem is of high status, unnamed, and loses her son but turns to a Yahwistic prophet to save him. The wife of Jeroboam has clear parallels with both: like Jezebel, she is a queen and her husband's house will end in violence, but like the woman of Shunem, she has no name and consults a Yahwistic prophet when her son falls sick. Her passivity, meanwhile, offers a point of comparison to Jezebel. While Jezebel is destructively dominant, Jeroboam's wife is passive and obedient. Although her silence could be a sign of subjugation, it may also serve to emphasize that this queen was not like Jezebel. Indeed, in consulting a Yahwistic prophet she models good behaviour, but ultimately her association with Jeroboam cannot go unpunished.

We should also note the mourning and burial for Abijah $(14: 13,18)$, which is usually glossed over by readers. In 1 Kgs 14:13 Ahijah says, “All Israel shall mourn for him (כל־ישראל וספדרל) and bury him; for he alone of Jeroboam shall come to the grave, because in him there is something pleasing to Yhwh, god of Israel, in the house of Jeroboam." Amidst the pain of the maternal grief the prophecy augurs, it offers a note of comfort for the wife of Jeroboam and places Abijah in significant company. In 1-2 Kings, the only other person who is mourned is a man of god (1 Kgs 13:29-30a): "he laid the body in his own grave and they mourned for him" (וינח את־נבלתו בקברו ויספדו עליו). Furthermore, the only person all Israel mourns in Samuel-Kings is Samuel himself (כל־ישראל ויספדרי־לו); 1 Sam 25:1; 28:3). David's men also mourn and weep for Saul and Jonathan (ויספדו ויבכו; 2 Sam 1:12a). All of these occurrences of ספל ויסו involve public mourning of important individuals, and Abijah is the only royal in Kings to receive such honour; even David himself is not mourned (1 Kgs 2:10-11). ${ }^{36}$ The theme of mourning in Samuel turns to formulaic death and burial

30 Hens-Piazza, Kings, 44.

311 Kings 14:5b says that the woman "pretended to be another woman," which might imply speech, but none is reported.

32 E.g., Provan, Kings, 117. On the fruitless nature of royal disguises in Kings, see Coggins, "Kings and Disguises.” Viewing this woman's disguise as foolish is unwarranted, however, for as Bodner notes, the instruction Jeroboam gives his wife refers to a plural: "disguise yourself so they will not know" (והשתנית ולא ידעו), meaning that the disguise is not for (the singular) Ahijah, but most likely for her protection while travelling among the people of Israel; Bodner, Jeroboam, 127.

33 E.g., Cohn, "Literary Technique," 26.

34 It may also parallel the downfall of the Elide house, as both the wife of Jeroboam and the wife of Phineas are unnamed and lose their children in events concerning Shiloh; Bodner, Jeroboam, 120-40, esp. 125-6.

35 Branch, "Spousal Abuse?” 256.

36 In 1-2 Samuel, mourning is used by the authors to make personal and political statements (see especially Zimran, "Look”). David mourns Abner (אבל, 2 Sam 3:31-39), Saul and Jonathan (2 Sam 1), Absalom (2 Sam 19:1-2), and Bathsheba's baby son (2 Sam 12:15-19), though he never mourns a woman. Women are, however, connected with mourning elsewhere in Samuel: Bathsheba mourns Uriah (ספד אבל, 2 Sam 11:26-27), the woman of Tekoa dresses as a mourning woman (2 Sam 14:2), and 
notices and occasional prophetic statements in Kings. ${ }^{37}$ As he was not a king, Abijah is not afforded the usual formulae but Ahijah's words are notable nonetheless. The emphasis on Abijah alone coming to his grave indicates the severe judgement on the house of Jeroboam but also provides some comfort to his mother. She cannot save him, but her son's correct burial and mourning rites would permit him an existence in the afterlife. It also offers a parallel to Josiah, who is told that disaster will come on Jerusalem but he himself would be "gathered to his grave in peace" (2 Kgs 22:15-20); judgement and comfort are intertwined in death for these two royal figures. Finally, the note that "in him there is something pleasing to Yhwh" is also a double-edged sword: it highlights Abijah's goodness but also denotes the northern kingdom's lost opportunity to found a righteous dynasty. ${ }^{38}$ Abijah and his mother thus further illustrate the themes found in $1 \mathrm{Kgs} 3$; children connected with royalty portend grief and kings endanger rather than save children.

If in $1 \mathrm{Kgs} 14 \mathrm{a}$ small note of comfort is found in correct burial and mourning, all comfort is lost in the siege and starvation of 2 Kgs 6:24-32. The king of Israel is depicted walking on the wall and confronted by an unnamed woman. Initially, he says he cannot help but then permits her to speak (6:26-27). She informs him that she made a pact with another woman to cook and eat her son one day and the other woman's son the next day, but the other woman reneged on the deal and hid her son. ${ }^{39}$ When the king hears her words, he tears his clothes, showing sackcloth beneath (6:30) and vows to kill Elisha (6:31-32). As much as readers desire one, the story has no resolution. The king is powerless and Elisha either does not want to or cannot help..$^{40}$ It is unclear whether the mothers kill their children in order to eat them or whether they had died already, though Parker notes that the woman would have more motive to hide a living child than a corpse. ${ }^{41}$ Cannibalism in times of desperation finds frequent expression in the Hebrew Bible, yet feminist scholars observe that the women of 2 Kgs 6 are criticized by numerous commentators. ${ }^{42}$ Hens-Piazza notes a few of the adjectives used by commentators to describe the women as "abominable, callous, shameless, inhuman." 43 Park states that the women are "condemned and dismissed, but rarely empathized with"; they are viewed as monsters, not mothers. ${ }^{44}$ Lanner, meanwhile, questions Lasine's "comic" reading and critiques Reinhartz's claim that this is cannibalism of the "worst sort" - a statement that implicitly places more blame on mothers than fathers. ${ }^{45}$ As these scholars observe, focusing only on the "moral depravity" of the women's actions risks making them the villains, not the victims. ${ }^{46}$ Yet, these mothers are victims, suffering the consequences of the decisions of men and a male god.

Rizpah's mourning highlights David's failings (2 Sam 21). For the latter two, see Kozlova, Maternal Grief, 87-119, 121-39. On Rizpah's story as a monument of counternarratives, see Joo, "Rizpah."

37 Good individuals in Kings "do what was right in the eyes of Yhwh," "act with might," and, most importantly, "sleep with their fathers." The absence of or deviation from the expected formulae mark disruption (Hutzli, "Epilogue Formulae"; Suriano, Politics). In particular, the desecration of Jezebel's body and the unique lack of burial of Athaliah stand out as major deviations from tradition. On the importance of graves and burials for children, see Flynn, Children, 131-40, and more broadly see Stavrakopoulou, Land of Our Fathers, 1-28.

38 Bodner, Jeroboam, 136.

39 The scene is reminiscent of the prostitutes in $1 \mathrm{Kgs} \mathrm{3}$, though in $2 \mathrm{Kgs} 6$ the complainant seeks the death/body of the child rather than the life of the child requested in 1 Kgs 3. See Hens-Piazza, Nameless, 97-103; Parker, Valuable and Vulnerable, 185-8.

40 Elisha has a mixed record with children (Parker, Valuable and Vulnerable, 197): he cursed 42 who were mauled by bears (2 Kgs 2:23-25), saves the children of the widow (2 Kgs 4:1-7), and saves the woman of Shunem's son (2 Kgs 4:8-37) but does not intervene here when starving mothers are eating their children. This episode does his (and Yhwh's) reputation no favours, as previous miracles showed that he could multiply food and bring children back from the dead, yet here he does nothing. 41 Parker, Valuable and Vulnerable, 178.

42 E.g., Lev 26:27-29; Deut 28:53; Jer 19:8-9; Ezek 5:10; Lam 2:20; 4:10.

43 Hens-Piazza, “Violence,” 101.

44 Park, Kings, 85.

45 Lanner, "Cannibal Mothers," 110-4. Lasine's ("Jehoram”) article makes some interesting points about the inversion of normality in the "world-upside-down-topos" signalled by a theme like parental cannibalism but, like Lanner, I do not agree with his comparison of this scene to the Levite in Judges 19 nor his identification of "comic" elements.

46 Hens-Piazza, Nameless, 92-4. 
The three narratives considered here all feature unnamed mothers, threatened sons, and kings. In Section 1, where royalty is absent, the children survive thanks to the prophets. Here, however, the damage is done by the institution of kingship - Solomon is wise but not a miracle-worker, Jeroboam's family suffers for the sins of the father, and the king of Israel is powerless in his capital city. On one level, the message is clear: kings endanger lives, prophets save them. In this sense, literary children are a useful illustrative tool, as their cultic-domestic value and their vulnerability increase their rhetorical potential. ${ }^{47}$ Ancient Near Eastern royal inscriptions thus use violence against children in military conflicts as a means of demonstrating the power of the victors and the impotence of those defeated. ${ }^{48}$ Violence against children is especially rhetorically impactful when establishing a deity's power in relation to someone. ${ }^{49}$ Here, the prophets' ability to save children places them in closer relationship to Yhwh than the kings who cannot prevent violence against the children they encounter. The female characters also uphold this ideology. Mothers who consult the Yahwistic prophets see their children saved (1 Kgs 17; 2 Kgs 4:1-7; 4:8-37) or at least buried with dignity (1 Kgs 14:1-18), while those who go to the kings lose their sons (1 Kgs 3; $2 \mathrm{Kgs} 6$ ).

The mothers also uphold ideologies of male expectations of motherhood, demonstrating, in particular, devotion to children. ${ }^{50}$ The women of Section 1 - the widow of Zarephath, the widow of 2 Kgs 4:1-7, and the woman of Shunem - are all praised by commentators for their determination and efforts to save their children. Any non-conforming behaviours displayed by these women are accepted because they result in the life of a child. Interestingly, no one praises the ingenuity of the woman who hid her child in $2 \mathrm{Kgs} 6$, nor the determination of Jeroboam's wife to travel to Ahijah at Shiloh, despite the similarity with the woman of Shunem's travel to Elisha. In reader responses, outcomes dictate reception of the means. Although their children do not survive, the biblical texts themselves do not condemn the mothers. In these cases, the women could not control the wider societal and cultural factors underlying their situations but respond to the threat to their children in the appropriate manner - devoted, desperate, grieving, and willing to go to great lengths to save them. Their actions may not merit praise, but they do not provoke condemnation from the biblical authors because they sought male guidance and fit male expectations of mothers. Through the paradigms of motherhood and maternal grief, the women become characterized and subject to the authorial agenda. The strategic use of these literary mothers becomes clear as we now turn to the depiction of the most important women in the monarchic history of Israel and Judah.

\section{The non-maternal mothers of kings}

1-2 Kings reports the names of the mothers of the kings throughout centuries of the Judahite monarchic rule, yet only four are given extended comments. ${ }^{51}$ In contrast to mothers elsewhere in the Hebrew Bible, they show no desperation to conceive children and are not portrayed raising children, showing concern for their well-being, or grieving and mourning when they die. Most queen mothers are limited to a brief mention of their name, origins, and son; their motherhood is acknowledged but reported only via their son and they have no agency themselves. ${ }^{22}$ In a few cases, the sins of the son are specifically related to the sins of the mother, but the righteousness of a son is never attributed to maternal (or female) influence. ${ }^{53}$ In $1-2$

47 Demonstrated in Flynn, Children; Parker, Valuable and Vulnerable.

48 Flynn, Children, 111-7; Cogan, "Pregnant Women;" Cogan and Tadmor, Kings, 80.

49 Flynn observes that almost all cases of violence against children make a comment on the deity's power or relationship with someone; Children, 117-8, 124-9, 171.

50 Implicit in devotion to children is a sense of subordination to husbands and to the wider patriarchal society; Fuchs, "Characterization."

51 On queen mothers in other ancient Near Eastern nations, see Brewer-Boydston, Good Queen Mothers, 30-50.

52 E.g., 1 Kgs 15:1-2; 22:41-42; 2 Kgs 18:1; 22:1.

53 Thus, Jezebel's son Ahaziah continued his mother's sins (1 Kgs 22:52-53) and Ahaziah son of Athaliah was influenced by the "House of Ahab" brought about by her presence (2 Kgs 8:27). Jehoram son of Jezebel (2 Kgs 3:2-3) and Asa son of Abijam 
Kings, a royal woman could lead a king down a dangerous path, but not a good one. ${ }^{54}$ We now turn to the few royal women who are permitted narratives in Kings: Bathsheba, Maacah, Jezebel, and Athaliah. A huge amount of literature has been devoted to these women, so I will focus specifically on their portrayal as mothers.

In Samuel, Bathsheba is almost a non-person, a flat character subordinated to the emphasis on David..$^{55}$ When her first husband dies, she mourns appropriately (2 Sam 11:26-27) and when her son becomes ill and dies, we hear indirectly that "David comforted Bathsheba his wife" (2 Sam 12:24). Although Uriah and the newborn son died as a consequence of sin, mourning and grief restore right order and out of this parental grief Solomon is born, whom Yhwh loved (2 Sam 12:24). ${ }^{56}$ In Kings, however, Bathsheba grows in status while David diminishes. ${ }^{57}$ Her presence is preferred to Abishag, who was beautiful but not a mother and her status is demonstrated physically by Solomon bowing to her and seating her on a throne (כסא 1 Kgs 2:19). ${ }^{58}$ Meanwhile, her political influence is signalled by Adonijah approaching her to gain the king's ear (1 Kgs 2:13-18). Her communication of Adonijah's request results - whether deliberately or not - in Adonijah's death (1 Kgs 2:22-25)..$^{59}$ Even though a son of David dies, Bathsheba is not condemned by the author, which contrasts with the reception of Jezebel and Athaliah's violence. Whereas those queens are lambasted for their slaughter of prophets and Davidic princes, Bathsheba is not critiqued, perhaps because men mediate the violence. ${ }^{60}$ Adonijah approaches Bathsheba of his own volition and Solomon alone decides his death based on her words; at no point does Bathsheba incite violence explicitly, unlike Jezebel and Athaliah. ${ }^{61}$ She does not overstep the boundaries of her role as queen mother and is thus a useful authorial character, demonstrating how royal female power could work acceptably beneath the male authority. While she mourned for Uriah, she does not mourn for David, but accepts the redefinition of her role from wife to queen mother and focuses her energy on her son.

While Bathsheba's actions are confined to her son and courtly politics, Maacah's influence was multigenerational and her actions religious. 1 Kings 15:2 introduces her as the daughter of Abishalom and mother of Abijam, but 15:10 also records her as the (grand)mother of Asa. Apparently, she made an image for Asherah and, consequently, Asa deposed her from her position as גבירה (15:13). The fact that Maacah was deposed from being גבירה has resulted in some viewing the role of גבירה as an official office.62 Yet, although גבירה is often translated "queen mother," the occurrences of the term elsewhere in the Hebrew

(1 Kgs 15:9-14) specifically do not follow their mother's sins. Rather, Asa's righteousness comes from his father David (15:11). Other kings' righteousness is also attributed to men: Jehoshaphat-Asa (1 Kgs 22:43); Joash-Jehoiada (2 Kgs 12:2); Amaziah - Joash (2 Kgs 14:3b); Azariah - Amaziah (2 Kgs 15:3); Jotham - Uzziah (2 Kgs 15:34); Hezekiah - David and Moses (2 Kgs 18:3-6); Josiah - David (2 Kgs 22:2).

54 Alongside mothers, foreign wives were also considered a threat. Solomon's foreign wives led him into sin (1 Kgs 11:1-10); Rehoboam's Ammonite mother seems connected to Judah's evil (1 Kgs 14:21-22); and Jezebel and Athaliah's origins lead their husbands astray (1 Kgs 16:31-32; 2 Kgs 8:18). The documented cases of this concern in 1-2 Kings are also limited to the tenth-ninth centuries BCE and culminate in Athaliah; Sergi, "Foreign Women," 196, 202, 206.

55 Berlin, "Characterization," 72-4. On Bathsheba as a mother, see Jacobs, "Mothering."

56 Long, "Brothers," 89, states that David taking Bathsheba caused a rupture in the relationship between David and Yhwh, which is healed following punishment, mourning, and the birth of a new son.

57 Brewer-Boydston, Good Queen Mothers, 149-53; Jacobs, "Mothering."

58 Jacobs argues that Bathsheba is characterized as a "mother-leader," proving her effectiveness in royal circles due to David's distractions. While she may appear unassuming on the surface, Jacobs views her as the mastermind of her son's succession and a "model of wisdom" ("Mothering," 77-9, 80-2).

59 Berlin, "Characterization," 75, notes that it is unclear whether Bathsheba conveyed the request out of naivety, jealousy for Abishag, or a presumption of Solomon's violent reaction. Brewer-Boydston, Good Queen Mothers, 154-6, argues that Bathsheba was fully aware of Adonijah's political intentions and acts to expose him and secure her son's reign.

60 It is not enough to say that Bathsheba's actions were excused because she acted on her son's behalf, as Jezebel acted on Ahab's behalf (1 Kgs 21) and Athaliah's actions are related to her son (2 Kgs 11:1). Acting for a man's benefit is thus not enough to merit a positive portrayal; what is at stake is how the woman acts for a man's benefit.

$611 \mathrm{Kgs}$ 18:4 claims that Jezebel cut down the prophets of Yhwh and 2 Kgs 11:1 states that Athaliah destroyed the royal seed; the focus is solely on the women's role in bloodshed.

62 Especially Andreasen, “Queen Mother.” 
Bible demonstrate that its meaning is broader than this. ${ }^{63}$ Translations of "lady" or "mistress" would be closer to the mark, but these usually carry strong connotations of femaleness. ${ }^{64}$ As the root of גבר is ", which signifies maleness, in particular, male strength, I wonder if something like "strong one" might be more accurate and offer more interpretive flexibility for conceptions of gender and power. ${ }^{65}$ Ackerman suggests that the association of Maacah with Asherah and the term גבירה indicates that the Judahite queen mother's role was connected to Asherah. ${ }^{66}$ The text is coy about the location of Maacah's image but the mention of Asa destroying it at the Wadi Kidron parallels Josiah's reform of the Jerusalem temple (esp. $2 \mathrm{Kgs}$ 23:6). If it was in the temple, then Maacah is the only woman in Kings to make changes to the Jerusalem temple, which was a seemingly solely male prerogative (e.g., 2 Kgs 16:10-18; 23:4-7). The king's reaction indicates that he had not given permission for her activity and her demotion on account of cultic activity is unparalleled in 1-2 Kings. When other reforming kings overhauled the temple, they did not depose individuals, which suggests that the real problem may have been Maacah's transgression of royal (female) boundaries, rather than the image itself. Maacah's double attribution of motherhood (1 Kgs 15:2, 10) denotes her continuing status but also the loss of her husband and son. By reporting only her transgression and not her reaction to these personal losses, the reader has no chance to sympathize with Maacah. Her motherhood is important insofar as it legitimized male power but once her status threatened male authority, it was swiftly removed.

In the passages pertaining to Jezebel (1 Kgs 16, 18, 19, 21; 2 Kgs 9), the ongoing dialectic between female power and masculinity becomes explicit. ${ }^{67}$ Her status - both hereditary and via her marriage alliance - is paralleled (and superseded) only by Athaliah in Judah. ${ }^{68}$ Lipka lists her masculine qualities as strength, leadership ability, having agency, violence, and preference for male company. ${ }^{69}$ She is credited with (negatively) influencing her husband's and son's rule of Israel (1 Kgs 16:31-32; 22:51-53), interfering in prophetic circles (1 Kgs 18:4, 13, 19), and inciting the elders to abuse their position and murder an innocent man (1 Kgs 21:1-16). Although she is often assumed to be all-dominant until her death, her influence seems to wane during her son Jehoram's rule. He explicitly was "not like his father and mother," did not support Baal (2 Kgs 3:2), and Jezebel is not mentioned in narratives concerning him. ${ }^{70}$ She only

63 See Ben-Barak, “Status and Right” and Brewer-Boydston, Good Queen Mothers, 14-6. The גבירות ings comprise the wife of Pharaoh (1 Kgs 11:19), Maacah (1 Kgs 15), the wife of Na'aman (2 Kgs 5:2), and an unnamed woman, either Jezebel or Athaliah (2 Kgs 10:13). Most commentators assume the latter is Jezebel, but I argue that it may refer to Athaliah; Quine, "Jehu's Slaughter.” Elsewhere, גבירה is applied to Nehushta (Jer 13:18; 29:2), a female ruler (Isa 47:5, 7), and the female equivalent of a master (Gen 16:4, 8, 9; Ps 132:2; Prov 30:23; Isa 24:2).

64 Thus, Bowen ("The Quest") argues for "great lady" or "principal lady."

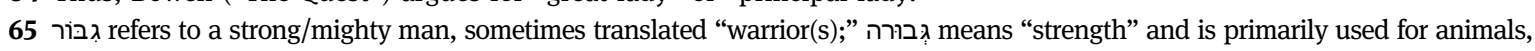

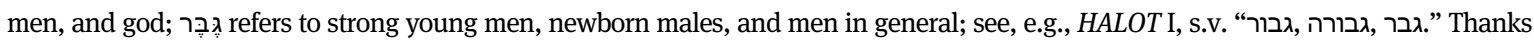
to Francesca Stavrakopoulou for starting me thinking along these lines. Svärd, Women and Power, 173, argues that the Mesopotamian texts do not portray gender directly; they portray social interactions and ideas about gender are derived from these. That actions create gender can be seen in the letters to royal women that call them "lord"; their actions resulted in the attribution of male titles. Perhaps we see something similar happening with the גבירות, wherein their actions and strength were akin to that of men and so they were given a title that signified male strength. If so, then גבירה would not be a formal office but a recognition of male qualities. Masculine grammar and gender discord may function similarly in the Book of Ruth; Quick, "My Lord the Queen.” In addition, Bergmann notes that "feminine" language and symbolism of childbirth is often applied to situations of male heroic acts or the status of men in crisis; Bergmann, Childbirth, 84-7, 91-103. Evidently, ideas of gender fluidity and power were interconnected.

66 Ackerman, "Queen Mother and the Cult," 389-91, 398-401; cf. Brewer-Boydston, Good Queen Mothers, 99-101.

67 See especially, Lipka, “Jezebel’s Masculinity;” Guest, “Transgender Gaze;” Kalmonofsky, Gender-Play, 51-66.

68 However, Dutcher-Walls, Jezebel, 23-7, notes that she is introduced more from what is said about Ahab marrying her than about her in her own right. The information about her background is surrounded by notices about Ahab doing evil, which casts aspersions on her character before she even begins to act.

69 Lipka, "Jezebel's Masculinity," 143-4. Interestingly, the woman of Shunem could be described as having all of these qualities, bar violence - even her relationship with Elisha and her husband is comparable to Jezebel's relationship to Ahab (Lipka, “Jezebel's Masculinity,” 144) but commentators do not highlight her masculinity. For the woman of Shunem, these qualities are praiseworthy; for queen Jezebel, they are condemnable. The difference may come, perhaps, in the fact that a woman could not usurp male prophetic power (which was granted by Yhwh) but could usurp male royal power. A masculine queen was perhaps a greater threat, therefore, than a non-royal masculine woman. 
reappears as a symbol of Omride/Ahabite rule when Jehu consolidates his (Deuteronomistic) coup and begins his elimination of political rivals (2 Kgs 9:30-37). ${ }^{71}$ Interestingly, Jezebel never mourns Ahab, despite their apparent closeness (1 Kgs 22:37-40), and she is absent from the bedside of her son Ahaziah when he was injured (2 Kgs 1:1-16). Messengers (1:2-8) and captains repeatedly attend their king (1:9-10, 11-12, 13-16), but his mother does not.72 She is not said to seek divine or magical help to save him (cf. the woman of Shunem and Jeroboam's wife). She is also distant from her other son Jehoram, and her reaction to Jehu approaching the gate of Jezreel - surely signalling Jehoram's death (2 Kgs 9:30 cf. 9:17-22) - is not grief, shock, or penitence. She does not tear her clothes and put ashes and sackcloth on, as one might expect of a parent learning of a son's death. ${ }^{73}$ Quite the opposite - she paints her eyes, adorns herself, and challenges Jehu's authority. ${ }^{74}$ McKinlay notes that masculinities and femininities are intertwined in this image; while this woman was, indeed, a woman, she did not act like one and women in Israel who do not act like women must be punished. ${ }^{75}$ In this performance of femininity and masculinity, Jezebel is a masculine woman, polemically portrayed as illegitimate in both genders. ${ }^{76}$ She is not a man and, due to her masculinity and omission of her motherhood, she is not presented as a "true" woman. ${ }^{77}$ Readers who identified with the pain and desperation of the non-royal bereaved mothers in 1-2 Kings find none of that in Jezebel's response to her sons' deaths. While images of Rachel "weeping for her children" and Rizpah standing vigil for her sons serve as paradigmatic images of maternal grief and devastation elsewhere, the image of Jezebel after her children's deaths is completely different.

Athaliah also responds unexpectedly to her son's death. Rather than mourning, tearing her clothes, weeping, fasting, or lamenting, when she sees that her son is dead, she arises to destroy all the royal seed of Judah (2 Kgs 11:1). ${ }^{78}$ Readers of Kings rarely bat an eyelid when a man wipes out the "house" of an opponent in order to take the throne - which may well have included the deaths of children. ${ }^{79}$ Athaliah's

70 In these passages, she functions more as an "associational model" than an active one; Dutcher-Walls, Jezebel, 63-4. 71 The ideology underlying the fixation on Jezebel is evident from her mention in the anointing of Jehu (2 Kgs 9:7; DutcherWalls, Jezebel, 72) and Jehu's reference to her "harlotries” and “sorceries” (זנוני איזבל עמך וכשפיה; 2 Kgs 9:22); Lipka, “Jezebel's Masculinity," 138-9.

72 Though Dutcher-Walls, Jezebel, 62, notes that the mention of Baal-zebub brings "Jezebel's lurking presence" into the story. 73 Compare, for example, the responses of Job (Job 1:18-20), Jacob (Gen 37:34-5), David (2 Sam 12:16-24; 19:1), Rizpah (2 Sam 21:10), and Jehoram (2 Kgs 6:30).

74 Lipka, “Jezebel’s Masculinity,” 140. Indeed, Stavrakopoulou (“Making Bodies”) notes that Jezebel’s gaze out of the window with her kohled eyes may signal ideas of the "gaze of the other - often couched as the evil eye" (p. 543), through which she "prepared to engage Jehu in the transaction of the dangerous gaze" (p. 546). Although some (e.g., Barré, Political Persuasion, 76-9) have viewed her self-styling as an attempt to seduce Jehu, or her adornment as that of a prostitute (Provan, Kings, 210), this is highly unlikely given her age (36 regnal years of Ahab-Ahaziah-Jehoram + age at marriage) and her sarcastic question, comparing Jehu to the doomed usurper Zimri; Park, Kings, 126-9. Hens-Piazza, Kings, 292, states that she appears "self-reliant and proud" and Tarlin, "Female' Reading," 215, notes that "women are not supposed to wield 'male' discourse" in the way that Jezebel does.

75 McKinlay, "Negotiating,” 307-8. Guest draws attention to Jehu's enhanced masculinity throughout 2 Kgs 9-10, observing that while Jehu is portrayed as a "man's man," Jezebel is emasculated by her feminizing make-up and hair styling; Guest, “Transgender Gaze," 58-68, 71-2. Just as Assyrian inscriptions present defeated enemies as emasculated (e.g., N'Shea, "Masculinity," 318-20, 327-31), so too is Jezebel emasculated. Moreover, through the parallel to Anat, Anat's female masculinity is also overthrown; Guest, "Transgender Gaze," 73-4.

76 In this light, it is perhaps interesting that she is thrown to her death by two eunuchs - men who were not fully men. 77 As Guest, "Transgender Gaze," 72, states, the Deuteronomist is in a "double bind" - "by demonstrating the dangers of female masculinity, he inevitably gives us sight of it."

78 Tearing clothes is one of the actions associated with grief that separates the mourners from people around them; Olyan, Biblical Mourning, 63-81. Athaliah tears her clothes and reacts emotionally to the coup against her (2 Kgs 11:14) but not to the death of her son, which reinforces her characterization as a power-hungry individual rather than a mother.

79 Baasha destroyed the house of Jeroboam and left "not one that breathed" (1 Kgs 15:27-29), Zimri wiped out the house of Baasha and "did not leave him a single male of his kindred or his friends" (1 Kgs 16:10-11), and Jehu had "the seventy sons" of Ahab and "forty-two brothers of Ahaziah" [of Judah] killed (2 Kgs 10:1-14). Solvang draws attention to the involvement of women in the royal houses of Judah, which prompts us to wonder about the fate of the women when men were wiping out each other's "houses”; Solvang, Royal Women, esp. 174-5. 
violence, however, is portrayed in relation to her maternal bereavement, creating an implicit contrast with the behaviour of other bereaved mothers in Kings and the Hebrew Bible. ${ }^{80}$ Athaliah is thus presented as an anti-mother, losing her own son and seeking to deprive others of theirs. ${ }^{81}$ This may also have animalistic connotations, as the image of an aggressive she-bear robbed of her cubs was evidently proverbial in ancient Israel (2 Sam 17:8; Hos 13:8; Prov 17:12). In addition, she is framed against the backdrop of ideal motherhood and legitimate rulership..$^{82}$ If femininity is rooted in motherhood and masculinity in rulership, then Athaliah fails at both. Like Jezebel, she is replaced by an appropriately male king, who is surrounded only by men and represents the supreme masculine deity. ${ }^{83}$ Yet, she is also replaced by an appropriately female woman. Macwilliam notes that Jehosheba's "perfect femininity" is displayed in her prioritizing the safety of a male above her own, saving his wet nurse, and retiring appropriately from the foreground of events. ${ }^{84}$ Athaliah's performance of power thus results in her completely blurring the boundaries between genders. If Jezebel is portrayed as a masculine queen mother, Athaliah's gender performance takes her beyond the authorial categories of male and female.$^{85}$ Rather than admit that the image of masculinity the royal, victorious, strong Yahwistic king - was redefined as a female role, the authors of kings attempt to remove Athaliah completely. Even Jehu thought to bury Jezebel, but Athaliah is not given a burial notice - she is erased from the world in silence. ${ }^{86}$

\section{Women and power: masculinity and motherhood}

When the royal women's narratives are considered purely in relation to each other, the lack of attention to details about their motherhood seems normative. It is only when we read the queens alongside the other women of Kings that the absence of motherhood and maternal grief becomes striking. I suggest that there are three explanations for this. First, the maturity rather than infancy of the kings naturally and politically lessens the emphasis on maternal nurture. Second, royal inscriptions/texts tend to emphasize male power/ achievements and female influence (of all kinds) wanes in comparison. Third, I contend that the presence of unnamed mothers in Kings is evidence of narratological politics. These women offer subversive parallels to the royal women who make the masculinity of the royal women appear aberrative rather than normative. Good women in Kings are characterized as subordinate mothers, for whom children are more important than any form of power.

The Neo-Assyrian inscriptions offer support for the interpretation of royal female roles in light of masculinity. In these texts, the queen or queen mother was the female equivalent of the king. ${ }^{87}$ Her administrative and economic importance is clear, and she is paralleled with the king in at least one sacrificial ritual. ${ }^{88}$ Two votive texts of especially prominent queens, Libbali-šarrat and Naqi'a, both

80 If there was an emotional explanation of her actions intended, such as her being driven mad at the news (Hens-Piazza, Kings, 306-7), the text does not explicate it, though at Ugarit, Pugatu mourns her brother Aqhatu by avenging his death (see Ames, "Red-Stained Warrior," 92-3). Violence or avenging a loved one's death as part of grief is seen occasionally with reference to men in the Hebrew Bible (e.g., 2 Sam 3:27 cf. 2 Sam 2:18-32) but not with reference to women, especially mothers. $\mathbf{8 1}$ Her destruction of her grandchildren biases the reader against her and makes her an "ideological caricature"; Kuloba, "Athaliah," 143, 152.

82 Kuloba, "Athaliah,” 143-4.

83 Apart from being rescued by Jehosheba, in $2 \mathrm{Kgs} 11$ Joash is entirely surrounded by men. During the coup, he is presented to the reader making covenants with men (2 Kgs 11:4), being surrounded by soldiers and priests (2 Kgs 11:5-19), and he "sits on the throne of kings" (11:19).

84 Macwilliam, "Athaliah: A Case of Illicit Masculinity,” 73-4.

85 Ibid., 79, notes that, in contrast to Athaliah, Jezebel never fully abandoned her femininity.

86 Ibid., 76-81.

87 Svärd, Women and Power, 87-143.

88 Ibid., 54, 84. 
mention their "reign" (palû) alongside the palû of the king and Naqi'a had the distinction of images of her likeness being installed in temples. ${ }^{89}$ There are also numerous examples of the queen/queen mother being addressed as "lord" (bēlu) as an honorific title. ${ }^{90}$ From the reign of Sennacherib onwards, women were involved in military matters. ${ }^{91}$ May observes that only one queen seems to be extolled for a "female quality," namely, Tašmētu-šarrat, "the palace lady, my beloved spouse, whose form the goddess Bēlet-ilī made more perfect than (that of) all (other) women."92 Interestingly, the kings were praised for their beauty more than the queens and with similar expressions; femininity does not seem to have been textually important when writing about a queen. ${ }^{93}$ Nor was fertility or childrearing textually important, though the symbol of the queens' seal was the scorpion, which was probably connected to ideas about defending and raising children..$^{94}$ Royal women do not generally appear connected with children in texts and, although we might assume that fertility was a female concern, it is praised in royal males and not mentioned in regards to royal women. ${ }^{95}$ The Neo-Assyrian inscriptions also do not depict the queen mothers mourning the dead kings, though SAA 2034 offers an example of a ritual enacted for the burial of a queen, during which the other queens cry out "[C]ome, [bu]ry the queen, the daughter of righ [teousness]." ${ }^{96}$ Most likely the authors of the Neo-Assyrian inscriptions, much like those of 1-2 Kings, did not wish to dwell on the deaths of the kings, which could create a politically unstable situation. Coronation rituals are more likely than mourning rituals to appear in inscriptions as crowning successors quickly would have discouraged usurpers and stressed the ongoing legitimacy and power of the office of kingship. ${ }^{97}$ In the Neo-Assyrian inscriptions, therefore, masculine performances of power by royal women are well attested and even praiseworthy.

I contend, therefore, that Kings does not just seek to emphasize male royal power but seeks to redefine female royal power. Whereas the kings could be rhetorically measured against David (good) and Jeroboam (bad), the standards for queens are set by Jezebel and Athaliah (both bad). No queen is endorsed as a comparative model of correct female behaviour. ${ }^{98}$ Rather, the rhetorical measure for queens seems to be motherhood - as the epitome of femininity and a signal of patriarchal subordination. ${ }^{99}$ The institution of motherhood permits comparison and (compulsory) feminization of women regardless of status. ${ }^{100}$ Thus,

89 Ibid., 81-2.

90 E.g., SAA 16 56; SAA 18 85; SAA 18 10; Svärd, Women and Power, 83.

91 They seem to have had command of their own units and Sammu-rammat is uniquely recorded as having gone on a campaign with her son Sennacherib; Svärd, Women and Power, 49-50, 53, 83-84.

92 May, "Neo-Assyrian Women," 275.

93 Ibid., 275-6.

94 For example, Radner, "The Seal of Tašmetum-šarrat," 690-2, notes that the female scorpion was called tāritzuqaqīqi "she who picks up the scorpion" and probably refers to the female scorpion's tendency to carry her young on her back. The scorpion served as a good image, therefore, for the queens protecting and defending their sons. Interestingly, this image connotes a measure of female aggression, seen also in the Hebrew Bible with regards to female bears (2 Sam 17:8; Hos 13:8; Prov 17:12) and perhaps lionesses (Ezek 19:2). The scorpion could have been connected to the goddess Ishara, whose emblem was also a scorpion; but as Svärd (Women and Power, 67-8, 74) notes, this proposal is tenuous.

95 May, "Neo-Assyrian Women," 276; although some examples of iconography may signal the queens' fertility and sexuality;

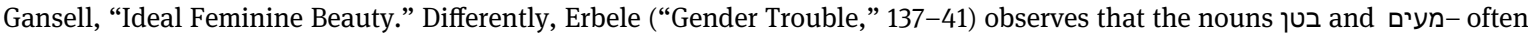
translated as "womb" - are also used of men in the Hebrew Bible and thus "are inner organs belonging to the non-sexed body." Language and conceptions surrounding fertility were evidently not always a female concern.

96 SAA 2034 rev.9-10. Van den Hout, "Death as a Privilege" (cf. Kozlova, Maternal Grief, 27-9), offers an example of a Hittite royal funerary ritual wherein the queen is not mentioned by title, but her presence seems implied in the idea of a mother accompanying her son to the next life, seen particularly in the "day of (his) mother" mentioned by the patili-priest.

97 SAA 207 records a royal coronation ritual in some detail, though it does not refer to any role or recognition of royal women at any point. Coronations are also more common than royal mourning in the Hebrew Bible; 1 Sam 10:1-2, 24-25; 11:14-15; 2 Sam 2:1-4; 5:1-4; 1 Kgs 1:32-40; 2 Kgs 11:17-20 are all examples of coronation rituals, whereas Saul is the only king who is explicitly mourned (2 Sam 1:12, 17).

98 The only candidate would be Bathsheba and she is neither explicitly praised nor used as a comparative model at any point. Macwilliam's (“Athaliah: A Case of Illicit Masculinity,” 75-6) comparison of Athaliah and the Queen of Sheba is interesting, as the latter rules as a monarch, yet underscores Solomon's masculinity. While the Queen of Sheba may function as an associative model, however, the biblical authors likely could not draw too much attention to her without legitimizing Athaliah's reign. 
via their motherhood and grief at the threatened loss of their children, the narratives about the widow of

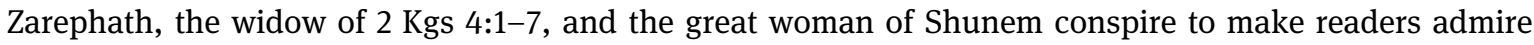
these women. Their role, devotion, and piety are divinely rewarded. The narratives about the mothers whose children die (1 Kgs 3; 14; 2 Kgs 6) also evoke sympathy from readers. The narratives about Maacah, Jezebel, and Athaliah, as non-maternal, non-grieving mothers, however, create discord with readers' expectations of women and motherhood and inspire condemnation. As van Wolde observes, characters become what they are in relation to others. ${ }^{101}$ The women of Kings are characterized in comparisons pious feminine mothers and evil masculine queens.

\section{Conclusions}

This essay has argued that the authors of 1-2 Kings use the institution of motherhood and the paradigm of maternal grief to polemicize against the institution of queenship and the gender fluidity it threatened. While Neo-Assyrian inscriptions attest the masculinity of royal female roles and even praise their queens and queen mothers as men, 1-2 Kings vilifies masculine gender performances of its royal women. The absence of femininity of queens and queen mothers in Neo-Assyrian texts appears unimportant, but the presence of numerous narratives about unnamed bereaved mothers in 1-2 Kings makes the absence of femininity in royal female figures there appear negative. The unnamed bereaved mothers of 1-2 Kings are all located in tenth-ninth-century Israel and Judah and precede the accounts of Jezebel and Athaliah's reigns, rendering their non-maternal portrayals and responses to their sons' deaths especially discordant for readers' expectations. The political use of maternal bereavement to enforce gender norms upholds scholarly observations of the importance of maternal grief in ancient Israel, as well as the literary uses of children in the Hebrew Bible. Furthermore, by aligning femininity with motherhood and masculinity with royal power, the authors present the queens as illegitimate in role and gender-Maacah, Jezebel, and Athaliah all seem more masculine than feminine and are all replaced by "real" men. The gender fluidity seen in the exercise or perception of power is thus authorially corrected and circumscribed; men are rulers, women are mothers. While male rulers could be compared to David or Jeroboam ben Nebat, royal women are compared to mothers or Jezebel/Athaliah. The triumph of motherhood as the measure of a woman has ultimately resulted in the queens and queen mothers - the most important women in Israel and Judah's monarchies - being demoted beneath any woman in the Bible who matches male expectations of the female role. Gender fluidity is aggressively undermined but simultaneously associated with great power.

\section{References}

Ackerman, Susan. "The Queen Mother and the Cult in Ancient Israel." Journal of Biblical Literature 112 (1993), 385-401. Ames, Frank R. "The Red-Stained Warrior in Ancient Israel." In Warfare, Ritual and Symbol in Biblical and Modern Contexts, edited by Brad E. Kelle, Frank Ritchel Ames, Jacob L. Wright, 83-140. AIAL 18. Atlanta, GA: Society of Biblical Literature, 2014.

99 Fuchs, "Characterization." We might also note the parallel with Deborah, who is connected with military leadership but praised specifically for being "a mother in Israel" (Judg 5:7).

100 As noted above, commentators readily judge the mothers of 1 Kgs 3 and 2 Kgs 6 and react to them very differently than they do to the widow of Zarephath or the woman of Shunem. This unfortunate tendency very much persists with regards to modern women.

101 Van Wolde, “Led by a Lady,” 355. 
Amit, Yairah. "A Prophet Tested: Elisha, the Great Woman of Shunem, and the Story’s Double Message.” Biblical Interpretation 11 (2003), 279-94.

Andreasen, Neals-Erik A. "The Role of the Queen Mother in Israelite Society." Catholic Biblical Quarterly 45 (1983), $179-94$. Barré, Lloyd M. The Rhetoric of Political Persuasion: The Narrative Artistry and Political Intentions of 2 Kings 9-11. CBQMS 20. Washington: Catholic Biblical Association of America, 1988.

Ben-Barak, Zafira. "The Status and Right of the Gěbîrâ." Journal of Biblical Literature 110 (1991), 23-34.

Berger, Yitzhak. “On Patterning In the Book of Samuel: 'News of Death' and the Kingship of David." Journal for the Study of the Old Testament 35 (2011), 463-81.

Bergmann, Claudia D. Childbirth as Metaphor for Crisis: Evidence from the Ancient Near East, the Hebrew Bible, and 1QH XI, 1-18. BZAW 382. Berlin: De Gruyter, 2008.

Berlin, Adele. “Characterization in Biblical Narratives: David's Wives." Journal for the Study of the Old Testament 7 (1982), 69-85.

Bodner, Keith. Jeroboam's Royal Drama. Biblical Refigurations. Oxford: Oxford University Press, 2012.

Bosworth, David A. “Faith and Resilience: King David's Reaction to the Death of Bathsheba's Firstborn." Catholic Biblical Quarterly 73 (2011), 691-707.

Bosworth, David A. "Understanding Grief and Reading the Bible." In Mixed Feelings and Vexed Passions in Biblical Literature: Emotions of Divine and Human Figures in Interdisciplinary Perspective, edited by F. Scott Spencer, 117-38. Resources for Biblical Studies 90. Atlanta, GA: Society of Biblical Literature, 2017.

Bowen, Nancy R. "The Quest for the Historical Gĕbîrâ." Catholic Biblical Quarterly 63 (2001), 597-618.

Branch, Robin Gallaher. "A Case of Spousal Abuse? A Study of the Marriage of Jeroboam I (1 Kings 14:1-18)." Old Testament Essays 22 (2009), 253-80.

Brewer-Boydston, Ginny. Good Queen Mothers, Bad Queen Mothers: The Theological Presentation of the Queen Mother in 1 and 2 Kings. CBQMS 54. Washington, DC: Catholic Biblical Association of America, 2015.

Cogan, Mordechai. “'Ripping Open Pregnant Women' in Light of an Assyrian Analogue.” Journal of the American Oriental Society 103 (1983), 755-7.

Cogan, Mordechai and Tadmor, Hayim. Il Kings: A New Translation with Introduction and Commentary. AYB. London: Yale University Press, 2008, repr. 1998.

Coggins, Richard. "On Kings and Disguises." Journal for the Study of the Old Testament 16 (1991), 55-62.

Cohn, Robert L. "Literary Technique in the Jeroboam Narrative." Zeitschrift für die alttestamentliche Wissenschaft 97 (1985), 23-35.

Cohn, Robert L. 2 Kings. Berit Olam. Collegeville, MN: Liturgical Press, 2000.

Dijk-Hemmes, Fokkelian van. "The Great Woman of Shunem and the Man of God: A Dual Interpretation of 2 Kings 4:8-37." In A Feminist Companion to Samuel and Kings, edited by Athalya Brenner, 218-30. Sheffield: Sheffield Academic Press, 1994.

Dutcher-Walls, Patricia. Jezebel: Portraits of a Queen. Interfaces. Collegeville, MN: Liturgical Press, 2004.

Erbele, Dorothea. “Gender Trouble in the Old Testament: Three Models of the Relation between Sex and Gender." Scandinavian Journal of the Old Testament 13 (1999), 131-41.

Flynn, Shawn W. Children in Ancient Israel: The Hebrew Bible and Mesopotamia in Comparative Perspective. Oxford: Oxford University Press, 2018.

Fuchs, Esther. "The Literary Characterization of Mothers and Sexual Politics in the Hebrew Bible." In Women in the Hebrew Bible: A Reader, edited by Alice Bach, 127-39. London: Routledge, 1999.

Galpaz-Feller, Pnina. "The Widow in the Bible and Ancient Near East." Zeitschrift für die alttestamentliche Wissenschaft 120 (2008), 231-53.

Gansell, Amy Rebecca. “Images and Conceptions of Ideal Feminine Beauty in Neo-Assyrian Royal Contexts, c. 883-627 BCE.” In Critical Approaches to Ancient Near Eastern Art, edited by Marian Feldman, Brian Brown, 391-420. Boston: De Gruyter, 2013.

Gray, John. I\&/l Kings, 3rd revised edn. OTL. London: SCM Press, 1977.

Guest, Deryn. “Modelling the Transgender Gaze: Performances of Masculinities in 2 Kings 9-10." In Transgender, Intersex and Biblical Interpretation, edited by Teresa J. Hornsby, Deryn Guest, 45-80. Atlanta: SBL Press, 2016.

Hens-Piazza, Gina. "Forms of Violence and the Violence of Forms - Two Cannibal Mothers Before a King (2 Kings VI, 24-33)." Journal of Feminist Studies in Religion 14 (1998), 91-104.

Hens-Piazza, Gina. Nameless, Blameless and Without Shame: Two Cannibal Mothers Before a King. Interfaces. Collegeville, MN: Liturgical Press, 2003.

Hens-Piazza, Gina. 1-2 Kings. AOTC. Nashville: Abingdon Press, 2006.

Hepner, Gershon. "Three's a Crowd in Shunem: Elisha's Misconduct with the Shunammite Reflects a Polemic against Prophetism." Zeitschrift für die alttestamentliche Wissenschaft 122 (2010), 387-400.

Hout, Theo P. J. van den. “Death as a Privilege: The Hittite Royal Funerary Ritual." In Hidden Futures: Death and Immortality in Ancient Egypt, Anatolia, the Classical, Biblical and Arabic-Islamic World, edited by J. M. Brenner, Th. P. J. van den Hout, R. Peters, 37-75. Amsterdam: Amsterdam University Press, 1994. 
Hutzli, Jürg. "Observations and Considerations on the Epilogue Formulae in Kings." In A King Like All the Nations? Kingdoms of Israel and Judah in the Bible and in History, edited by M. Oeming, P. Sláma, 177-94. BVB 28. Zürich: LIT Verlag, 2015. Jacobs, Mignon R. “Mothering a Leader: Bathsheba's Relational and Functional Identities." In Mother Goose, Mother Jones, Mommie Dearest: Biblical Mothers and Their Children, edited by Cheryl Kirk-Duggan, Tina Pippin, 67-84. Semeia Studies 61. Atlanta, GA: Society of Biblical Literature, 2009.

Janzen, J. Gerald. "The Root Škl and the Soul Bereaved in Psalm 35." Journal for the Study of the Old Testament 65 (1995), 55-69.

Joo, Samantha. "Counter-Narratives: Rizpah and the 'Comfort Women' Statue." Journal for the Study of the Old Testament 44 (2019), 79-98.

Joyce, Paul. "Lamentations and the Grief Process: A Psychological Reading." Biblical Interpretation 1 (1993), 304-20.

Kalmonofsky, Amy. "Women of God: Maternal Grief and Religious Response in 1 Kings 17 and 2 Kings 4." Journal for the Study of the Old Testament 36 (2011), 55-74.

Kalmonofsky, Amy. Gender-Play in the Hebrew Bible: The Ways the Bible Challenges Its Gender Norms. London: Routledge, 2016.

Kozlova, Ekaterina E. Maternal Grief in the Hebrew Bible. OTM. Oxford: Oxford University Press, 2017.

Kuloba, Robert W. “Athaliah of Judah (2 Kings 11): A Political Anomaly or an Ideological Victim?" In Looking Through a Glass Bible: Postdisciplinary Biblical Interpretations from the Glasgow School, edited by A. K. M. Adam, Samuel Tongue, 139-52. BibInt 125. Leiden: Brill, 2014.

Lanner, Laurel. “Cannibal Mothers and Me: A Mother's Reading of 2 Kings 6:24-7:20.” Journal for the Study of the Old Testament 24 (1999), 107-16.

Lasine, Stuart. “Jehoram and the Cannibal Mothers (2 Kings 6.24-33): Solomon's Judgement in an Inverted World.” Journal for the Study of the Old Testament 50 (1991), 27-53.

Lasine, Stuart. "Matters of Life and Death: The Story of Elijah and the Widow's Son in Comparative Perspective." Biblical Interpretation 12 (2004), 117-44.

Lee, Archie Chi Chung. “Mothers Bewailing: Reading Lamentations.” In Her Master's Tools: Feminist and Postcolonial Engagements of Historical-Critical Discourse, edited by Caroline Vander Stichele, Todd Penner, 195-210. Atlanta, GA: SBL, 2009.

Lipka, Hilary. “Queen Jezebel's Masculinity.” In Biblical Masculinities Anew, edited by Ovidiu Creangă, 125-50. Sheffield: Sheffield Phoenix Press, 2019.

Long, Burke 0. "A Darkness Between Brothers: Solomon and Adonijah.” Journal for the Study of the Old Testament 6 (1981), 79-94.

Long, Burke O. 2 Kings. FOTL X. Grand Rapids, MI: Eerdmans, 1991.

May, Natalie N. "Neo-Assyrian Women, Their Visibility, and Their Representation in Written and Pictorial Sources." In Studying Gender in the Ancient Near East, edited by Saana Svärd, Agnès Garcia-Ventura, 249-88. University Park, Pennsylvania: Eisenbrauns, 2018.

Macwilliam, Stuart. "Athaliah: A Case of Illicit Masculinity.” In Biblical Masculinities Foregrounded, edited by Ovidiu Creangă, Peter Ben-Smit, 69-85. HBM 62. Sheffield: Sheffield Phoenix Press, 2017.

McKinlay, Judith E. "Negotiating the Frame for Viewing the Death of Jezebel." Biblical Interpretation 10 (2002), 305-23.

N'Shea, Omar. "Empire of the Surveilling Gaze: The Masculinity of King Sennacherib." In Studying Gender in the Ancient Near East, edited by Saana Svärd, Agnès Garcia-Ventura, 315-35. University Park, Pennsylvania: Eisenbrauns, 2018.

Olyan, Saul. Biblical Mourning: Ritual and Social Dimensions. Oxford: Oxford University Press, 2011.

Park, Song-Mi Suzie. 2 Kings. Wisdom Commentary 12. Collegeville, MN: Liturgical Press, 2019.

Parker, Julie Faith. Valuable and Vulnerable: Children in the Hebrew Bible, Especially the Elisha Cycle. Brown Judaic Studies 355. Providence, RI: Brown University, 2013.

Parpola, Simo. Assyrian Royal Rituals and Cultic Texts. SAA 20. Helsinki: Neo-Assyrian Text Corpus Project, 2017.

Provan, lain W. 1 and 2 Kings. NIBC. Peabody, MS: Hendrickson, 1995.

Quick, Laura. "My Lord the Queen: Gender Discord in Comparative Perspective." Hebrew Bible and Ancient Israel 48 (2019), 448-63.

Quine, Cat. “Jehu's Slaughter of Judah's Royal Family at Beth-Eked (2 Kings 10:13-14): A Closer Look.” Zeitschrift für die alttestamentliche Wissenschaft 131 (2019), 537-48.

Radner, Karen. “The Seal of Tašmetum-šarrat, Sennacherib’s Queen, and Its Impressions.” In Leggo! Studies Presented to Frederick Mario Fales on the Occasion of His 65th Birthday, edited by Giovanni Lanfranchi, Daniele Bonacossi, Cinzia Pappi, Simonetta Ponchia, 687-98. Leipziger Altorienalische Studien 2. Wiesbaden: Harrasowitz, 2012.

Roncace, Mark. "Elisha and the Woman of Shunem: 2 Kings 4:8-37 and 8:1-6 Read in Conjunction." Journal for the Study of the Old Testament 25 (2000), 109-27.

Sered, Susan Starr. “Mother Love, Child Death, and Religious Innovation: A Feminist Perspective.” Journal of Feminist Studies in Religion 12 (1996), 5-23.

Sergi, Omer. "Foreign Women and the Early Kings of Judah: Shedding Light on the Historiographic Perception of the Author of Kings." Zeitschrift für die alttestamentliche Wissenschaft 126 (2014), 193-207.

Shemesh, Yael. "Elisha and the Miraculous Jug of Oil (2 Kgs 4:1-7)." Journal of Hebrew Scriptures 8 (2008), 1-18. 
Shields, Mary E. "Subverting a Man of God, Elevating a Woman: Role and Power Reversals in 2 Kings 4." Journal for the Study of the Old Testament 18 (1993), 59-69.

Solvang, Elna. A Woman's Place is in the House: Royal Women of Judah and their Involvement in the House of David. JSOTS 349. Sheffield: Sheffield Academic Press, 2003.

Stavrakopoulou, Francesca. Land of Our Fathers: The Roles of Ancestor Veneration in Biblical Land Claims. LHBOTS 473. London: Bloomsbury T\&T Clark, 2010.

Stavrakopoulou, Francesca. "Making Bodies: On Body Modification and Religious Materiality in the Hebrew Bible." Hebrew Bible and Ancient Israel 2 (2013), 532-53.

Suriano, Matthew J. The Politics of Dead Kings: Dynastic Ancestors in the Book of Kings and Ancient Israel. FAT 2. Tübingen: Mohr Siebeck, 2010.

Svärd, Saana. Women and Power in Neo-Assyrian Palaces. SAAS XIII. Helsinki: The Neo-Assyrian Text Corpus Project, 2015. Sweeney, Marvin A. I and II Kings: A Commentary. OTL. Louisville, KY: Westminster John Knox Press, 2007.

Tarlin, Jan. "Toward a 'Female' Reading of the Elijah Cycle: Ideology and Gender in the Interpretations of 1 Kings 17-19, 21 and 2 Kings 1-2:18." In A Feminist Companion to Samuel and Kings, edited by Athalya Brenner, 208-17. Sheffield: Sheffield Academic Press, 1994.

Wiley, Henriette L. "They Save Themselves Alone: Faith and Loss in the Stories of Abraham and Job." Journal for the Study of the Old Testament 34 (2009), 115-29.

Wolde, E. J. van. “A Leader Led By A Lady: David and Abigail in I Samuel 25.” Zeitschrift für die alttestamentliche Wissenschaft 114 (2002), 355-75.

Wyatt, Stephanie. "Jezebel, Elijah, and the Widow of Zarephath: A Ménage à Trois that Estranges the Holy and Makes the Holy the Strange." Journal for the Study of the Old Testament 36 (2012), 435-58.

Zhixiong, Niu. 'The King Lifted up His Voice and Wept': David's Mourning in the Second Book of Samuel. Rome: Gregorian and Biblical Press, 2013.

Zimran, Yisca. “'Look, the King is Weeping and Mourning!': Expressions of Mourning in the David Narratives and their Interpretive Contribution.” Journal for the Study of the Old Testament 41 (2018), 419-517. 